\title{
Arab EFL Learner Perceptions of English Phonemes: A Cross-Language Phonetic Interference
}

\author{
Taif Al-Kinany ${ }^{1}$, Abdullah Al-Abri ${ }^{1} \&$ Hafid Ambusaidi ${ }^{2}$ \\ ${ }^{1}$ English Language Centre, University of Technology and Applied Sciences, Nizwa, Oman \\ ${ }^{2}$ Business Studies Department, University of Technology and Applied Sciences, Nizwa, Oman \\ Correspondence: Abdullah Al-Abri, English Language Centre, University of Technology and Applied Sciences, \\ Nizwa, Oman.
}

Received: January 5, 2022

Accepted: January 30, 2022

Online Published: January 30, 2022

doi: 10.5539/elt.v15n2p67

URL: https://doi.org/10.5539/elt.v15n2p67

\begin{abstract}
The extant studies addressing second language phonetic perception assume that second language phonemes are perceived to be similar to first language phonemes, and tend to be substituted by learners of English as a foreign language. This study aimed to assess the perceptual relationship between the phonemes of English and the sound units of Omani Arabic of the Al-Dakhiliyah region to discover the extent of the influence exerted by Omani Arabic on the perception of English phonemes by Omani learners. Two instruments were constructed to achieve this goal: first, the Omani phonetic system was elucidated via a questionnaire and the consonants and vowels uttered by the Omani people were archived as a phonetic dialect; second, a test was created to examine the perceptual phonetic distance between Omani Arabic and English phonemes. This investigation was designed to test the hypothesis of the revised speech learning model. The results confirmed the model's postulation that learners instinctively and reflexively associate the second language sounds to the phonetic groups of their first language.
\end{abstract}

Keywords: pronunciation, perception, first language acquisition, second language learning, segmental features, EFL class

\section{Introduction}

A literature survey on Omani Arabic (OA) dialects revealed a scant number of studies in this area. As-Sammer (2010), Holes (1989), Jayakar (1889), Rhodokanakis (1908) and a few other researchers have studied some features of the phonology, morphology and grammar of OA dialects. Omani dialects have almost identical grammars; notable differences occur in phonetics, phonology and morphology. English and Arabic are two characteristically different languages, specifically apropos their phonological systems. The phonological features of both languages are similar in some respects and distinctive in others. The distinguishing attributes are found either in their segmental alphabet or in their phonotactic rules (Al Hosni, 2014). The outcomes obtained by previously conducted investigations indicate that Omani college students studying English as a foreign language (EFL) encounter remarkable pronunciation-related difficulties both in the segmental and the suprasegmental aspects.

Most of these obstacles are believed to relate to the differences in the orthographic systems of English, the incompatible associations between English spellings and pronunciations and the divergences in the sound systems of Arabic and English. Omani students of English encounter numerous pronunciation challenges apropos consonants, consonant clusters, vowels, diphthongs and words used in connected speech. Regional Omani differences also pose serious pronunciation difficulties represented by mother tongue interferences with English phonation (Thakur, 2020).

English as a second language or EFL learners face major difficulties in achieving an acceptable pronunciation that can be understood by native speakers. In fact, many EFL learners may master elements of English such as syntax, morphology, or even semantics but often fail to attain phonological competence. According to Avery (1992), the nature of a foreign accent is determined largely by the learner's mother tongue. In other words, the sound system of the first language (L1) exerts a real impact on the pronunciation of the target language.

The elucidation of foreign or second language (L2) pronunciation errors may reveal a critical need for awareness in EFL teachers about the extent of the influence applied by the L1 phonological systems of learners on the English learning context. A contrastive phonological analysis of the L1 of learners vis-à-vis English as the target 
language may offer EFL teachers useful pedagogical insights in this context. Contrastive analyses can also help EFL teachers examine particular phonological characteristics of English on which they should concentrate. Such comparisons would also contribute to the knowledge of instructors about the existing relationships between language systems. Teachers across the world may find such discriminatory analyses efficacious in dealing with the learning obstacles their students confront, especially with respect to the phonological aspects of the language (Hall, 2007).

This study explored the extent to which the segmental phonological characteristics of OA L1 interfered with the perceptions of Omani EFL learners about English phonemes. Thus, it aimed to test the hypothesis of perceived cross-language dissimilarity posited by the revised speech learning model (SLM-r), which asserts that

learners subconsciously and automatically relate L2 sounds to L1 phonetic categories, and that the greater is the perceived phonetic dissimilarity of realisations of an L2 phonetic category from the realisations defining an L1 category, the more likely a new phonetic category will be formed for the L2 sound (Flege \& Bohn, 2021).

Accordingly, this study intended to achieve the following:

1) List the phonemes of the Omani dialect spoken in the Al-Dakhiliyah region.

2) Specify the English phonemes that Omani EFL learners of the Al-Dakhiliyah region find difficult to perceive.

3) Assess the perceptual relationship between the phonemes of English and the OA of the Al-Dakhiliyah region.

4) Examine the extent to which OA influences the segmental perception of Omani EFL learners.

\subsection{Research Questions}

Q1: What Arabic phonemes are produced in the Al-Dakhiliyah region of Oman?

Q2: What English phonemes do Omani EFL learners of the Al-Dakhiliyah region find difficult to perceive?

Q3: What is the perceptual relationship between the phonemes of English and of OA of the Al-Dakhiliyah region?

Q4: To what extent does OA influence the perception of English phonemes by Omani EFL learners?

\subsection{Significance of the Study}

No initiative attempting to archive a phonology dialect of OA was found in the extant literature with respect to the mother tongue perceptual interference of EFL learners. However, some similar studies have been conducted on the intelligibility of Omani EFL learners have probed this issue (Al-Humaidi \& Al-Belushi, 2014; Al Yaqoobi et al., 2016; As-Sammer, 2010; Thakur 2020). The present study tested the SLM-r hypotheses with respect to the phonetic perception of Omani EFL learners and focused on the segmental features of the phonology of OA found in the Al-Dakhiliyah region of Oman.

\section{Literature Review}

The possible impact of L1 on L2 learning has long been investigated, and the body of knowledge on this topic has advanced considerably in the last few decades. Best (1995) and Best and Tyler (2007) perception assimilation model (PAM) is an influential theory on the influence of $\mathrm{L} 1$ on both the production and perception of L2. PAM, specifically PAM-L2, focuses on the perception aspect of L2 acquisition and studies how L2 learners assimilate/dissimilate a new L2 sound according to their L1 phonology categories. Intensive research endeavours have adopted this model, suggesting multifarious reasons for the L1 influences on L2 and indicating phonology, phonetics or a combination of the two elements as the principal cause.

Investigations of phonetic issues in second language acquisition must examine both segmental and suprasegmental features; however, this study was confined to the segmental features of the phonetic systems of OA and RP English. Phonetics is the study of sounds. Crystal (2003) explains the term 'phonetics' as a 'Linguistic sub discipline that studies the phonetic aspect of speech with regard to the following processes: (a) articulatory-genetic sound production (articulatory phonetics); (b) structure of the acoustic flow (acoustic phonetics) and (c) neurological-psychological processes involved in perception (auditory phonetics)'. The physiology of the human body must be understood to grasp the mechanics of human languages. Letters represent sounds in a rather intricate manner, a fact that denotes both advantages and disadvantages. The international phonetic alphabet was created to accurately and uniformly represent sounds through letters (Kracht, 2007). 
Roach (2002) stated that 'In any language we can identify a small number of regularly used sounds (vowels and consonants) that we call phonemes'.

This study utilised qualitative and quantitative data to offer insights for the measurement of the phonetic distance between languages using RP English and OA as a test case. RP English is not a monolithic entity; it comprises a variety of speech styles that may be categorised by Parsons (1998) according to several dimensions: age (conservative, mainstream and advanced); social status (hyperlect, acrolect and paralect); situation (formal and familiar) and social class (defined by various affinities such as education, recreation, walk of life or habitat; e.g. sophisticated city-dweller vs. country squire). Gimson (1970) also distinguished between

the conservative RP forms used by the older generation and, traditionally, by certain professors or social groups; the general RP forms most commonly in use and typified by the pronunciation adopted by the BBC; and the advanced RP forms mainly used by young people of exclusive social groups.

Roach (2009) also added the following:

Languages have different accents [...] The accent that we concentrate on and use as our model is the one that is most often recommended for foreign learners studying British English. It has for a long time been identified by the name Received Pronunciation (usually abbreviated to its initials, RP), ... it is most familiar as the accent used by most announcers and newsreaders on $\mathrm{BBC}$ and British independent television broadcasting channels, a preferable name is $\mathrm{BBC}$ pronunciation.

OA, however, is a daughter dialect of the mother tongue Arabic, a Semitic language belonging to the Afro-Asiatic family. Specifically, Arabic is related to the Central South Semitic family (Ferguson, 1997; Watson, 2002). OA is spoken in discrete areas, including the Sultanate of Oman, Kenya, Tanzania and parts of the United Arab Emirates. Two principal varieties of Arabic are used in contemporary Oman: Modern Standard Arabic (MSA) and the spoken version of Arabic labelled OA. MSA is the language of mass media, official ceremonies and religious and public speeches (Shaaban, 1977). More significantly, it is the medium of instruction in Omani schools, colleges and educational institutions. OA, conversely, is the spoken language of native Omanis. It is diverse in its phonology and morphology and utilises different lexical terms (Shaaban, 1977). Holes (1989), however, stated that 'The fact that Oman is a large country ... with a varied topography which includes vast deserts, impassable mountain ranges and fertile coastal planes ... [implies that] a considerable degree of dialectal diversity would be found there'.

\section{Methodology}

\subsection{Method}

This research was approved by the Research Committee at the author's university. Written informed consent was obtained from the study participants prior to testing. Two phonetic tests were constructed to accomplish the study objective: the first sought to design an archive of the Omani phonetic system, specifically to the Al-Dakhilyah Omani dialect and the test named Speech Accent Archive of Al-Dakhilyah (SAAAD); the second aimed to measure the perceptual phonetic distance between SAAAD and RP English. The experiments were essentially designed to discover the RP English sounds that evince simple and minimal differences in SAAAD, to list the RP phonemes that are difficult for Omani students to perceive and to assess the perceptual relationships between the phonemes of RP English and SAAAD depending on the SLM-r hypothesis of perceived cross-language dissimilarities. This postulation reads,

learners subconsciously and automatically relate L2 sounds to L1 phonetic categories, and that the greater is the perceived phonetic dissimilarity of realisations of an L2 phonetic category from the realisations defining an L1 category, the more likely a new phonetic category will be formed for the L2 sound (Flege \& Bohn, 2021).

\subsection{Sample}

The sample of the current study comprised thirteen Omani university instructors employed at the University of Technology and Applied Sciences in the Al-Dakhiliyah region, a governorate (muhafazah) of Oman with Nizwa town as its regional centre. The Al-Dakhiliyah governorate encompasses eight provinces (wilayat): Nizwa, Samail, Bahla, Adam, Al Hamra, Manah, Izki and Bid Bid. This sample of instructors was selected for their linguistic competence in Arabic as their mother tongue and was engaged in this study to take the first test as the group of study subjects. It was also believed that the first test would assist this group in formulating its responses to the first measures proposed by the study. 
Further, a sample of 30 Omani EFL students of the English Language Centre of the University of Technology and Applied Sciences in the Al-Dakhiliyah region were picked to take the second test. The selection of this sample was based on the evidence of sufficient English proficiency by the university EFL learners.

\subsection{Procedures}

Both groups of subjects described above were required to take a phonetic test. In the first production test, the participating instructors were asked to use only OA to answer some questions. The term 'phonetic transcription' denotes a system of symbols used for the written notation of spoken language. The spoken utterances of the test subjects were recorded, phonemically transcribed and analysed using the PRAAT software.

The second test involved the perceptual recognition of phonetic elements and required the participating students to listen to each English phoneme being pronounced in different positions in three words. The students were then asked to indicate whether or not the given sound occurred in OA.

The first test (see Appendix A) was intended to enable the compilation of a phonetic system of Omani vowels and consonants (a phonology dialect archive). The second test (see Appendix B) purposed to measure the perceptual phonetic distances between OA and English.

\subsection{Materials and Design}

Test one was a production test in which Omani instructors were required to only use OA to answer seven questions. The instructors represented the perfect sample through which to assess the segmental phonology of the OA spoken in the Al-Dakhiliyah region because they all reported that they were born in the Al-Dakhiliyah region and resided there. All seven questions of the test enquired about their career.

The items pertaining to the second test were distributed over two columns. Each item was exemplified using three words. The items were distributed according to the articulatory classification of the phonemes as well as by the position of the phoneme, i.e., the initial sound except for $/ \mathrm{y} / \mathrm{and} / 3 /$ because these appear at the ends of words. This phonemic written test examined perceptual recognition, and the subjects were asked to respond to its items by providing two OA words that contained the specified sounds.

The tests were presented to a jury of specialists in linguistics and English language teaching to ensure the validity of the items and to recommend any modifications that would improve the instrument and help to achieve the study's objectives. Consequently, face validity was adopted. The researchers also executed pilot studies of the two tests before performing their final application.

\subsection{Recording Sessions}

A laptop, a recording facility and the computer PRAAT software were utilised for the recording of the data of the first test. A pre-elicitation session was implemented before starting the recording to reduce strain. The participants were instructed to read the questions and then to use only OA in their answers. The time taken to record each subject ranged between ten and fifteen minutes. The recorded material was later downloaded, phonemically transcribed and analysed.

\subsection{Data Elicitation}

The subjects for the first test were asked to answer all test items based on instructions and guidance provided by the researchers. All recordings were accomplished depending on the availability of the informants in a very quiet room that was extremely conducive for this exercise. The researchers did not intervene during the test in any way. No interruption occurred in the performance of the test.

A list of monosyllabic and disyllabic English words comprising 24 English consonant phonemes and twenty vowels was compiled for the second test. The subjects were asked to provide two OA words that contained a specified phoneme, as described below in the section detailing the second test.

All data obtained from the administration of the two tests were input to the PRAAT software for phonetic auditory analysis. The perceived dissimilarities were assessed using the method recommended for the evaluation of perceived cross-language phonetic dissimilarities. The accuracy with which the given phonemes were produced was appraised both acoustically and through the judgement of the listeners.

\subsection{Analysis}

The obtained results were submitted to a group of Omani Arab teachers of English at the English Language Centre of the University of Technology and Applied Sciences. The score-rescore method was deployed to confirm the reliability of the results of both tests. The final test data were given to a group of Omani university 
educators for the assessment of the definitive results. SPSS analyses were utilised to compute the statistical outcomes of the second test.

\subsection{Test 1}

The short speeches made by all the test subjects were recorded by the researcher and were phonemically transcribed. A phonemic analysis was subsequently performed to achieve an archive of the phonology of the dialect of OA spoken in the Al-Dakhiliya region. The findings were calculated, and the sounds produced by the entire sample were considered for the SAAAD table below. It was found that the Omani people of the Al-Dakhilyah region produced specific Arabic phonemes (see Appendix C).

\subsection{Test 2}

The data obtained from this test were examined and analysed, and the results pertaining to the phonemic distances between English and OA phonemes are presented in Appendix D.

\section{Results}

The analysis of the two tests indicated that there are six English vowels and diphthongs, as Table 1 indicates, that do not occur in OA.

Table 1. Vowels and diphthongs that do not exist in OA (Al-Dakhilyah region)

\begin{tabular}{llll}
\hline$/ \Lambda /$ & up & $/$ ea/ & $\underline{\text { air }}$ \\
$/$ oə/ & poor & $/ 3: /$ & sir \\
$/$ Iə/ & ear & $/ \mathrm{p} /$ & shop
\end{tabular}

The results also indicated that three English consonants, as shown in Table 2, do not have a counterpart in OA.

Table 2. Consonants that do not exist in OA (Al-Dakhilyah region)

/p/ put $/ \mathrm{p} / \quad$ ring $/ \mathrm{v} /$ visit

As Table 3 shows, the analyses of this study also revealed that three English sounds that Omani people rarely use.

Table 3. Sounds rarely uttered by the Omani people

\begin{tabular}{ll}
\hline$/ \mathrm{e} /$ & set \\
$/ \mathfrak{e} /$ & map \\
$/ \mathrm{oi} /$ & boy \\
\hline
\end{tabular}

As Table 4 illustrates, a group of vowels and diphthongs are used in OA.

Table 4. Vowels and diphthongs that exist in OA (Al-Dakhilyah region)

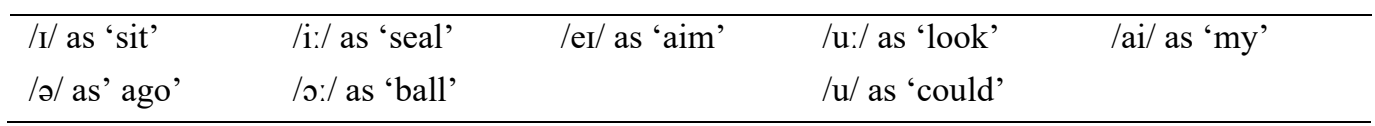

In addition, some English consonants, as Table 5 shows, can be detected in OA.

Table 5. Consonants that exist in OA (Al-Dakhilyah region)

\begin{tabular}{llll}
\hline$/ \mathrm{b} /$ & $\underline{\text { book }}$ & $/ \mathrm{w} /$ & $\underline{\text { what }}$ \\
$/ \mathrm{k} /$ & cake & $/ \mathrm{j} /$ & yes \\
$/ \mathrm{g} /$ & go & $/ \mathrm{d} /$ & $\underline{\text { this }}$ \\
$/ \mathrm{f} /$ & $\underline{\text { fine }}$ & $/ \theta /$ & $\underline{\text { thin }}$ \\
$/ \mathrm{l} /$ & $\underline{\text { light }}$ & $/ \mathrm{s} /$ & $\underline{\text { sun }}$ \\
$/ \mathrm{m} /$ & $\underline{\text { moon }}$ & $/ \mathrm{z} /$ & $\underline{\text { zoo }}$ \\
$/ \mathrm{n} /$ & $\underline{\text { noon }}$ & $/ \mathrm{t} /$ & $\underline{\text { talk }}$ \\
$/ \mathrm{r} /$ & $\underline{\text { right }}$ & $/ \mathrm{d} /$ & $\underline{\text { door }}$ \\
$/ \mathrm{g} /$ & $\underline{\text { shy }}$ & $\mathrm{h} /$ & $\underline{\text { high }}$
\end{tabular}

The phonemes $/ \mathrm{t} \mathrm{f} / \mathrm{d} 3 /$ and $/ 3 /$ were deemed critical because they are occasionally used only by the Omani people who live in the Al Hamra district of the Al-Dakhilyah region. However, the current study sample did not produce any of these phonemes during the experimental session. 
The analyses of the obtained results yielded the following findings:

1) The Omani dialect of the Al-Dakhilyah region exercised a substantial impact on the English pronunciation of native OA users. This outcome confirms the hypothesis of the considerable phonetic distance between RP English and OA since the two target dialects belong to two distinct language families.

2) The variant $/ \mathrm{g} /$ evinced a higher rating in the Al-Dakhilyah region in comparison to the variant $/ \mathrm{d} 3 /$. The scored rankings revealed that the Al-Dakhilyah area is phonologically characterised by the use of $/ \mathrm{g} /$ rather than $/ \mathrm{d} 3 /$. Interestingly, however, the $/ \mathrm{d} 3 /$ phoneme was noted in the production of one subject.

3) A significant difference was observed between the ability of subjects to recognise English vowels and their capacity to identify English consonants.

4) The subjects performed very well in providing OA words containing sounds approximating the given English examples with all the tested sounds except for $/ \mathrm{p} /, / \mathrm{d} 3 /, / \mathrm{t} / /, / \mathrm{n} /, / 3 /$ and almost all the vowel sounds.

\subsection{Discussion of the Perception of Phonemic Closeness}

\begin{tabular}{|c|c|c|c|c|c|c|c|c|}
\hline \multirow{4}{*}{ 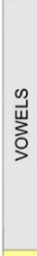 } & \multicolumn{4}{|c|}{ monophthongs } & \multicolumn{2}{|c|}{ diphthongs } & \multirow{2}{*}{\multicolumn{2}{|c|}{$\begin{array}{r}\text { Phonemic } \\
\text { Chart } \\
\text { voiced } \\
\text { unvoiced }\end{array}$}} \\
\hline & $\begin{array}{c}\mathrm{i}: \\
\text { sheep }\end{array}$ & $\begin{array}{c}\text { I } \\
\text { ship }\end{array}$ & $\underset{\text { good }}{U S}$ & $\begin{array}{l}\text { U: } \\
\text { shoot }\end{array}$ & $\begin{array}{l}\text { IO } \\
\text { here }\end{array}$ & $\begin{array}{l}\text { eI } \\
\text { wait }\end{array}$ & & \\
\hline & $\underset{\text { bed }}{e}$ & $\begin{array}{c}\partial \\
\text { teacher }\end{array}$ & $\begin{array}{l}\text { 3: } \\
\text { bird }\end{array}$ & $\begin{array}{l}\text { O: } \\
\text { door }\end{array}$ & $\begin{array}{l}\text { Uəurist } \\
\text { tout }\end{array}$ & $\begin{array}{l}\text { OI } \\
\text { boy }\end{array}$ & $\begin{array}{l}\partial \mho \\
\text { show }\end{array}$ & \\
\hline & $\begin{array}{l}æ \\
\text { cat }\end{array}$ & $\begin{array}{l}\Lambda \\
\text { up }\end{array}$ & $\begin{array}{l}\text { Q: } \\
\text { far }\end{array}$ & $\begin{array}{l}\text { D } \\
\text { on }\end{array}$ & $\begin{array}{l}\text { eə } \\
\text { hair }\end{array}$ & $\begin{array}{c}\text { aI } \\
\mathrm{my}\end{array}$ & $\begin{array}{l}\text { av } \\
\text { cow }\end{array}$ & \\
\hline \multirow{3}{*}{ 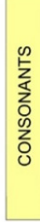 } & $\underset{\text { pea }}{p}$ & $\begin{array}{c}\mathrm{b} \\
\text { boat }\end{array}$ & $\underset{\text { tea }}{\mathrm{t}}$ & $\begin{array}{l}\text { d } \\
\text { dog }\end{array}$ & $\underset{\text { cheese }}{t 5}$ & $\begin{array}{l}\text { dz } \\
\text { June }\end{array}$ & $\begin{array}{l}\mathrm{k} \\
\mathrm{car}\end{array}$ & $\begin{array}{l}\text { g } \\
\text { go }\end{array}$ \\
\hline & $\underset{f l y}{f}$ & $\begin{array}{c}\text { Video } \\
\text { vide }\end{array}$ & $\underset{\text { think }}{\theta}$ & $\underset{\text { this }}{\partial}$ & $\begin{array}{l}\text { S } \\
\text { see }\end{array}$ & $\begin{array}{l}\mathbf{Z} \\
\mathbf{Z} 00\end{array}$ & $\int_{\text {shall }}$ & $3_{\text {television }}^{3}$ \\
\hline & $\begin{array}{l}\mathrm{m} \\
\text { man }\end{array}$ & ${ }_{\text {now }}^{n}$ & $\eta_{\text {sing }}^{\eta}$ & $\begin{array}{l}\mathrm{h} \\
\text { hat }\end{array}$ & $\underset{\text { love }}{1}$ & $\underset{\text { red }}{r}$ & $\begin{array}{l}\text { W } \\
\text { wet }\end{array}$ & $\underset{\text { yes }}{\mathrm{j}}$ \\
\hline
\end{tabular}

Figure 1. English Phonemic Chart

Table 6. OA (Al-Dakhilyah region) phonemic

\begin{tabular}{|c|c|c|c|c|c|c|c|c|c|}
\hline \multirow{3}{*}{ vowels } & \multicolumn{4}{|c|}{ monophthongs } & \multicolumn{5}{|c|}{ diphthongs } \\
\hline & $/ \mathrm{i} /$ & $/ \mathrm{u} /$ & /o:/ & $/ \mathrm{a} /$ & /au/ & & /ai/ & & \\
\hline & /i:/ & /u:/ & $/ \mathfrak{m} /$ & /a:/ & /ou/ & & /ei/ & & \\
\hline & $/ \mathrm{b} /$ & $/ \mathrm{t} /$ & $/ \mathrm{d} /$ & $/ \mathrm{k} /$ & $/ g /$ & $/ \mathrm{s} /$ & $|z|$ & {$[\mathrm{h}]$ as in $\tau$} & $/ \mathrm{t} /$ \\
\hline consonants & $/ 1 /$ & $/ \mathrm{r} /$ & $/ \mathrm{w} /$ & $\mid \mathrm{j} /$ & $/ \mathrm{m} /$ & $/ \mathrm{n} /$ & $/ \mathrm{f} /$ & {$\left[\mathrm{t}^{\mathrm{c}}\right]$ as in $b$} & [q] as in ق \\
\hline & ص ص & $/ \mathrm{s} /$ & $|z|$ & $\theta$ & ð & [D & {$[\mathrm{x}]$ as in $\dot{\tau}$} & [y] as in $\dot{\varepsilon}$ & [S] as in $\varepsilon$ \\
\hline
\end{tabular}

Tables 7 and 8 are generated from the compilation of Figure 1 and Table 6. On one hand, as illustrated in Table 7, some English phonemes (e.g. /ol/, /dz/, /eə/, etc.) are phonemically distanced from OA sound units. This means they are rarely used by Al-Dakhilyah people.

Table 7. English phonemes that are distanced from OA

\begin{tabular}{ll}
\hline$/ \mathrm{t} /$ & $/ \mathrm{y} /$ \\
$/ \mathrm{p} /$ & $/ 3 /$ \\
$/ \mathrm{v} /$ & $/ \mathrm{d} /$ \\
$/ \mathrm{o} /$ & $/ \mathrm{I} /$ \\
$/ \mathrm{e} /$ & $/ \mathrm{e} /$ \\
$/ 3: /$ & $/ \mathrm{vo} /$ \\
$/ \mathrm{N} /$ & $/ \mathrm{ra} /$ \\
\hline
\end{tabular}

On the other hand, as shown in Table 8, some English phonemes (e.g. /b/, /m/,/d/, etc.) are close to OA sound units. Thus, they are commonly used in the Al-Dakhilyah region. 
Table 8. English phonemes that are close to OA

\begin{tabular}{llllll}
\hline$/ \mathrm{b} /$ & $/ \mathrm{l} /$ & $/ \mathrm{g} /$ & $/ \mathrm{w} /$ & $/ \mathrm{s} /$ & \\
$/ \mathrm{k} /$ & $/ \mathrm{m} /$ & $/ \mathrm{h} /$ & $/ \mathrm{j} /$ & $/ \mathrm{z} /$ & \\
$/ \mathrm{g} /$ & $/ \mathrm{n} /$ & $/ \mathrm{t} /$ & $/ \mathrm{d} /$ & & \\
$/ \mathrm{f} /$ & $/ \mathrm{r} /$ & $/ \mathrm{d} /$ & $/ \theta /$ & & \\
$/ \mathrm{i} /$ & $/ \mathrm{u} /$ & $/ \mathrm{o} / /$ & $/ \mathrm{a} /$ & $/ \mathrm{au} /$ & $/ \mathrm{ai} /$ \\
$/ \mathrm{i} / /$ & $/ \mathrm{u} / /$ & $/ \mathfrak{x} /$ & $/ \mathrm{a} / /$ & $/ \mathrm{ou} /$ & $/ \mathrm{ei} /$ \\
\hline
\end{tabular}

The following assertions are thus highlighted based on the SLM-r:

The majority of Omani EFL learners are likely to experience serious phonetic problems with the phonemes listed in Table 9.

Table 9. Problematic English phonemes

\begin{tabular}{|c|c|}
\hline$/ \mathrm{t} \int /$ & $/ \mathrm{y} /$ \\
\hline$/ \mathrm{p} /$ & $\mid 3 /$ \\
\hline$/ \mathrm{v} /$ & $/ \mathrm{d}_{3} /$ \\
\hline $\begin{array}{l}\text { /o/ } \\
\text { /e/ }\end{array}$ & $\begin{array}{l}\text { /oI/ } \\
\text { /ea/ }\end{array}$ \\
\hline $\begin{array}{l}\text { /3:/ } \\
\mid \mathrm{A} /\end{array}$ & $\begin{array}{l}\text { /va/ } \\
\text { / } /\end{array}$ \\
\hline
\end{tabular}

However, no Omani EFL learner is likely to experience phonetic problems with the sounds listed in Table 10.

Table 10. Non-problematic English phonemes

\begin{tabular}{llllll}
\hline$/ \mathrm{b} /$ & $/ \mathrm{l} /$ & $/ \mathrm{g} /$ & $/ \mathrm{w} /$ & $/ \mathrm{s} /$ & \\
$/ \mathrm{k} /$ & $/ \mathrm{m} /$ & $/ \mathrm{h} /$ & $/ \mathrm{j} /$ & $/ \mathrm{z} /$ & \\
$/ \mathrm{g} /$ & $/ \mathrm{n} /$ & $/ \mathrm{t} /$ & $/ \mathrm{d} /$ & & \\
$/ \mathrm{f} /$ & $/ \mathrm{r} /$ & $/ \mathrm{d} /$ & $/ \theta /$ & & \\
$/ \mathrm{i} /$ & $/ \mathrm{u} /$ & $/ \mathrm{o} / /$ & $/ \mathrm{d} /$ & $/ \mathrm{au} /$ & $/ \mathrm{ai} /$ \\
$/ \mathrm{i} / /$ & $/ \mathrm{u} / /$ & $/ \mathfrak{} /$ & $/ \mathrm{a} / /$ & $/ \mathrm{ou} /$ & $/ \mathrm{ei} /$
\end{tabular}

It is worth mentioning that Omani EFL learners are likely to find the following minimal pairs phonetically problematic:

i. /f/ and $/ \mathbf{v} /$ as in fast and vast

ii. $/ \mathbf{p} /$ and $/ \mathbf{b} /$ as in put and but

iii. $/ \mathbf{g} /$ and $/ \mathbf{d} \mathbf{3} /$ as in go and gym

iv. $/ \mathbf{d} \mathbf{z} /$ and $/ \mathbf{z} /$ as in measure and June

v. $/ \mathbf{J} /, / \mathbf{3} /, / \mathbf{t} /$ and $/ \mathbf{d} \mathbf{z} /$ as in shy, treasure, chimney and Jug

vi. /e/ and /i/ as in sit and set

vii. /o/and/u/ as in shop and shoot

\subsection{Hypothesis Verification}

The SLM-r hypothesis tested in this study states that 'the greater the phonetic distance between L1 and L2 sounds, the more likely it is that learners will categorise L2 sounds in a native-like fashion'. The results of the current investigation are congruent with this theory and thus serve to validate the SLM-r.

\section{Conclusion}

The present study aimed to examine the reorganisation of phonetic systems over individual life-spans in response to phonetic inputs received during natural L2 learning. Put differently, it re-scrutinised the validity of the SLM-r. The researchers concluded that the creation of new phonetic categories for EFL phonemes depends primarily on the precision of mother tongue categories attained through the quantity and quality of the perceived L2 input as well as the apprehension of the phonetic dissimilarities of the EFL sounds vis-à-vis the most proximate L1 sound unit. This study initially compiled an archive of the phonology of the OA dialect specific to the Al-Dakhiliyah region of Oman. Next, the English sounds that Omani EFL learners find difficult to perceive were investigated in comparison to the phonemes of their mother tongue. Finally, the SLM-r hypothesis was validated through 
experiments evidencing that Omani EFL learners subconsciously related English sounds to the existing OA phonetic categories.

\section{Acknowledgements}

We would like to thank The Research Council in Oman for funding this project. Also, we appreciate The University of Technology and Applied Sciences - Nizwa in Oman for their collaboration in conducting this research.

\section{Funding Details}

The research project was funded by The Research Council (Grant number: BFP/RGP/EHR/20/184) in Oman.

\section{References}

Al Hosni, S. (2014). Speaking difficulties encountered by young EFL learners. International Journal on Studies in English Language and Literature, 2(6), 22-30.

Al-Humaidi, S., \& Al-Belushi, J. (2014). Investigating EFL Omani learners' ability to produce English phonics in taught words and in untaught words. Arab World English Journal, 5(2), 54-69.

As-Sammer, M. A. A. S. (2010). Phonological variation in modern standard Arabic: The case of the Affricate/ds: Oman as a sample. Journal of Basrah Researches, 36(4), 29-57.

Avery, P. (1992). Teaching American English pronunciation. New York: Oxford University Press.

Best, C. T. (1995). A direct realist view of cross-language speech perception. Timonium, MD: York Press.

Best, C. T., \& Tyler, M. D. (2007). Nonnative and second-language speech perception. In Ocke-S. Bohn, \& M. J. Munro (Eds.), Language (pp. 3-12). Amsterdam, the Netherlands: John Benjamins.

Crystal, D. (2003). English as a global language (2nd ed.). Cambridge: Cambridge University Press. https://doi.org/10.1017/CBO9780511486999

Ferguson, C. A. (1997). Structuralist studies in Arabic linguistics: Charles A. Ferguson's Papers, 1954-1994 (Vol. 24). Leiden, the Netherlands: Brill.

Flege, J. E., \& Bohn, O.-S. (2021). The revised speech learning model (SLM-r). In R. Wayland (Ed.), Second language speech learning: Theoretical and empirical progress (pp. 3-83). Cambridge: Cambridge University Press. https://doi.org/10.1017/9781108886901.002

Gimson, A. C. (1970). An introduction to the pronunciation of English. London: Edward Arnold.

Hall, D. C. (2007). The role and representation of contrast in phonological theory. Toronto: University of Toronto.

Holes, C. (1989). Towards a dialect geography of Oman. Cambridge: Cambridge University Press. https://doi.org/10.1017/S0041977X00034558

Jayakar, A. S. G. (1889). The O'manee dialect of Arabic. Journal of the Royal Asiatic Society of Great Britain and Ireland, 21(3), 649-687. https://doi.org/10.1017/S0035869X00165839

Kracht, M. (2007). Introduction to linguistics. Los Angeles: Campbell Hall. Retrieved from https://linguistics.ucla.edu/people/Kracht/courses/ling20-fall07/ling-intro.pdf

Parsons, M. B. (1998). A review of procedural acceptability in organizational behavior management. Journal of Organizational Behavior Management, 18(2-3), 173-190. https://doi.org/10.1300/J075v18n02_09

Rhodokanakis, N. (1908). The vulgar Arabic dialect in Dofar (Zfar). Wien: Holder.

Roach, P. (2002). English phonetics and phonology: A practical course. Cambridge: Cambridge University Press.

Roach, P. (2009). English phonetics and phonology paperback with audio CDs (2): A practical course. Cambridge: Cambridge University Press.

Shaaban, K. A. (1977). The phonology of Omani Arabic. Austin: University of Texas.

Thakur, V. S. (2020). Phonological problems of Omani EFL learners: Pedagogical perspectives and implications. Arab World English Journal, 11(March). https://doi.org/10.24093/awej/vol11 1no1.3

Watson, J. C. E. (2002). The phonology and morphology of Arabic. Oxford: Oxford University Press.

Yaqoobi, A., Mohammed, Z., Ali, F., \& Sulan, N. (2016). An analysis of errors caused by Omani EFL learners in pronouncing certain consonant sounds. International Journal of Language Education and Applied Linguistics. 


\section{Appendix A}

Test 1: Speech dialect archive

Please use only Omani Arabic to respond to the following questions.

1) What do you do?

2) Why did you choose to work at the University of Technology and Applied Sciences?

3) How many hours per day do you work?

4) What do you enjoy most about your work?

5) What are some of the challenges you face in your work?

6) How do you handle the stresses and pressures of your work?

7) Do you prefer to work alone or in a team?

\section{Appendix B}

\section{Test 2: The perceptual phonetic distance}

Dear students,

Listen to each sound being pronounced in three words in column B and indicate whether or not the specified sound is found in Omani Arabic. Next, provide two Omani Arabic words containing the particular sound.

\begin{tabular}{|c|c|c|c|c|c|}
\hline Column A & $\begin{array}{l}\text { Column B } \\
\text { Words }\end{array}$ & $\begin{array}{l}\text { This sound is } \\
\text { found in Omani } \\
\text { Arabic }\end{array}$ & $\begin{array}{l}\text { Two Omani } \\
\text { words } \quad \text { using } \\
\text { specified sound }\end{array}$ & $\begin{array}{r}\text { Arabic } \\
\text { the }\end{array}$ & $\begin{array}{l}\text { This sound is not } \\
\text { found in Omani } \\
\text { Arabic }\end{array}$ \\
\hline$/ \mathrm{p} /$ & pin -put-paul & & & & \\
\hline$/ \mathrm{b} /$ & ball - back- bird & & & & \\
\hline$/ \mathrm{k} /$ & come- cook - cake & & & & \\
\hline /g/ & good -goal-game & & & & \\
\hline$/ \mathrm{f} /$ & fan -fire -film & & & & \\
\hline$/ \mathrm{v} /$ & vase -very -van & & & & \\
\hline /1/ & live -love-like & & & & \\
\hline$/ \mathrm{m} /$ & moon -my -milk & & & & \\
\hline$/ \mathrm{n} /$ & nice -noon -night & & & & \\
\hline$/ \mathrm{r} /$ & right -road -read & & & & \\
\hline$/ \mathrm{d}_{3} /$ & june -july -jacket & & & & \\
\hline$/ \mathrm{s} /$ & shirt -shy -shoes & & & & \\
\hline$/ \mathrm{t} \int /$ & choose-chin -chair & & & & \\
\hline$/ \mathrm{h} /$ & house -hear -his & & & & \\
\hline$/ \mathrm{t} /$ & tall- take-today & & & & \\
\hline$/ \mathrm{d} /$ & done -day -do & & & & \\
\hline$/ \mathrm{y} /$ & wing -king -ring & & & & \\
\hline /w/ & what -one-when & & & & \\
\hline /j/ & yet-yes -yesterday & & & & \\
\hline /ð/ & this - that - those & & & & \\
\hline$/ \theta /$ & thrill-thin -thumb & & & & \\
\hline$/ \mathrm{s} /$ & sea-sick-slim & & & & \\
\hline $\mid \mathrm{z} /$ & zinc-zoo- zero & & & & \\
\hline
\end{tabular}




\begin{tabular}{|c|c|}
\hline $\mid 3 /$ & -pleasure -garage \\
\hline /I/ & sit-mint-fit \\
\hline /e/ & bed-red-said \\
\hline$/ \mathfrak{~} /$ & sad -bad- map \\
\hline$/ \mathfrak{p} /$ & hall-roll-fall \\
\hline$/ \Lambda /$ & love-up-mud \\
\hline$/ \mho /$ & pull-bush-put \\
\hline /i:/ & seat-need-feed \\
\hline /ei/ & main-rain -way \\
\hline /ai/ & nice- fine-right \\
\hline /oI/ & toy-boy-annoy \\
\hline /u:/ & soon-tool-fool \\
\hline /ov/ & bow-no- so \\
\hline /av/ & cow-now-how \\
\hline /ea/ & dare-where-wear \\
\hline /ia/ & dear-hear-rear \\
\hline /a:/ & card -bar- far \\
\hline |o:/ & call- tall-mall \\
\hline /ひə/ & pure-fewer-cure \\
\hline$|3:|$ & burn-shirt-first \\
\hline /a/ & away -ago-about \\
\hline
\end{tabular}

\section{Appendix C}

\begin{tabular}{|c|c|c|c|c|c|c|c|c|c|}
\hline \multicolumn{10}{|c|}{ Phonemes Produced by Omanis in Al-Dakhilyah Region } \\
\hline & monophthong & & & & Dipl & hongs & & & \\
\hline \multirow[t]{2}{*}{ vowels } & /i/ & $/ \mathrm{u} /$ & /o:/ & $/ \mathrm{a} /$ & /au/ & & & & /ai/ \\
\hline & /i:/ & /u:/ & $/ æ /$ & /a:/ & /ou/ & & & & /ei/ \\
\hline \multirow[t]{3}{*}{ consonants } & $/ \mathrm{b} /$ & $/ \mathrm{t} /$ & $/ \mathrm{d} /$ & $/ \mathrm{k} /$ & $/ \mathrm{g} /$ & $/ \mathrm{s} /$ & $|z|$ & $/ \mathrm{h} /$ & {$[\mathrm{h}]$ as in $\mathrm{\tau}$} \\
\hline & $/ 1 /$ & $/ \mathrm{r} /$ & $/ \mathrm{w} /$ & $/ \mathrm{j} /$ & $/ \mathrm{m} /$ & $/ \mathrm{n} /$ & {$\left[t^{\mathrm{c}}\right]$ as in $b$} & & [q] as in \\
\hline & [s'] as in ص & $/ \mathrm{s} /$ & $|z|$ & $\theta$ & $Đ$ & [D & {$[\mathrm{x}]$ as in $\dot{\tau}$} & {$[\gamma]$ as in $\dot{\varepsilon}$} & {$[\mathrm{C}]$ as in $\varepsilon$} \\
\hline
\end{tabular}

\section{Appendix D}

Phonemic distance in percentages (the proximity of English phonemes to native Omani Arab linguistic sound units)

\section{Consonants}

phoneme

Phonemic distance in percentage

phoneme

Phonemic distance in percentage

phoneme

Phonemic distance in percentage

Plosives

/p/ $\quad 20 \%$

/b/

$100 \%$

$/ \mathrm{t} /$

$100 \%$

$100 \%$

$/ \mathrm{k} /$

$100 \%$

/d/

$/ \mathrm{g} /$

$100 \%$

\section{Affricates}

$/ \mathrm{t} /$

$20 \%$

$/ \mathrm{d} 3 /$

$6 \%$ 


\begin{tabular}{|c|c|c|c|c|c|}
\hline \multicolumn{6}{|c|}{ Fricatives } \\
\hline$/ \mathrm{s} /$ & $100 \%$ & /ठ/ & $100 \%$ & $/ \mathrm{f} /$ & $100 \%$ \\
\hline $\mid \mathrm{z} /$ & $100 \%$ & $/ \theta /$ & $100 \%$ & $/ \mathrm{v} /$ & $20 \%$ \\
\hline$/ \mathrm{J} /$ & $100 \%$ & & & & \\
\hline$|3|$ & $6 \%$ & & & & \\
\hline \multicolumn{6}{|l|}{ Nasals } \\
\hline$/ \mathrm{n} /$ & $100 \%$ & $/ \mathrm{m} /$ & $100 \%$ & $/ \mathrm{y} /$ & $20 \%$ \\
\hline \multicolumn{6}{|l|}{ Lateral } \\
\hline /1/ & $100 \%$ & & & & \\
\hline \multicolumn{6}{|l|}{ Gliding } \\
\hline$/ \mathrm{r} /$ & $100 \%$ & $/ \mathrm{w} /$ & $100 \%$ & $/ \mathrm{j} /$ & $100 \%$ \\
\hline \multicolumn{6}{|l|}{ Vowels } \\
\hline phoneme & $\begin{array}{l}\text { Phonemic distance } \\
\text { in percentage }\end{array}$ & phoneme & $\begin{array}{l}\text { Phonemic distance } \\
\text { in percentage }\end{array}$ & phoneme & $\begin{array}{l}\text { Phonemic distance } \\
\text { in percentage }\end{array}$ \\
\hline \multicolumn{6}{|l|}{$\begin{array}{l}\text { Short } \\
\text { vowels }\end{array}$} \\
\hline /i/ & $86 \%$ & /e/ & $40 \%$ & /3:/ & $13 \%$ \\
\hline$/ \mathrm{u} /$ & $20 \%$ & $/ æ /$ & $86 \%$ & $|\partial|$ & $40 \%$ \\
\hline$/ \Lambda /$ & $33 \%$ & $/ \mathrm{p} /$ & $40 \%$ & & \\
\hline \multicolumn{6}{|l|}{$\begin{array}{l}\text { Long } \\
\text { vowels }\end{array}$} \\
\hline /i:/ & $66 \%$ & /u:/ & $60 \%$ & & \\
\hline /o:/ & $20 \%$ & /a:/ & $20 \%$ & & \\
\hline \multicolumn{6}{|c|}{ Diphthongs } \\
\hline /iə/ & $73 \%$ & /ea/ & $6 \%$ & /Oa/ & $26 \%$ \\
\hline /ei/ & $40 \%$ & /ai/ & $40 \%$ & /oi/ & $13 \%$ \\
\hline$/ \mathrm{au} /$ & $20 \%$ & /ou/ & $20 \%$ & /ou/ & $13 \%$ \\
\hline
\end{tabular}

\section{Copyrights}

Copyright for this article is retained by the author(s), with first publication rights granted to the journal.

This is an open-access article distributed under the terms and conditions of the Creative Commons Attribution license (http://creativecommons.org/licenses/by/4.0/). 